\title{
Ensuring sustainable development of higher education on the basis of digital educational services
}

\author{
Natalya Usova*, Mikhail Loginov, and Elvira Nedorostkova \\ Ural Institute of Management, Russian Presidential Academy of National Economy and Public \\ Administration, Ekaterinburg, Russia
}

\begin{abstract}
In the context of national economy digital transformation and global challenges impact, the development trends of digital educational services are becoming more and more relevant. In the given article, scientific papers on various aspects of educational services digitization are reviewed. The authors proposed an original approach to the category of "digital educational service", and revealed stages of digital educational services formation. To identify trends in the digital educational services development and the impact of the novel Covid-19 coronavirus infection pandemic on this process the authors analysed digital learning services development in the higher education market from 2016 through 2020. Based on the research results, main trends of higher education development were revealed and prospects for digital educational services development in the medium term were identified.
\end{abstract}

\section{Introduction}

Vigorous introduction of digital technologies at the global level and the need to ensure the national economy competitiveness have led to a change in priorities while providing sustainable development of both national economy as a whole and its structural elements. One of these elements is the higher education system with its direct influence on the competitiveness of the national economy and its macroeconomic indicators.

In the higher education system, the quality of educational services is of major importance, allowing to contribute to the national economy with highly qualified employees and to successfully compete with the leading educational institutions at the international level.

As a consequence, it seems important to focus on the development trends identification in digital educational services, as well as on the impact of the pandemic on the higher education sustainable development in the Russian Federation.

\section{Materials and methods}

The given research is based on the works by the authors who considered various aspects of digital transformation of educational services. Certain issues of educational services

\footnotetext{
* Corresponding author: nata-ekb-777@yandex.ru
} 
digitization were reflected in the works by: Bykovskaya E.N. [1], Vasilyeva M.V. [11], Velichko O.A. [7], Veselitsky O.I. [2], Dogadina V.Yu. [3], Latov Yu.V. [4], Latova N.V. [4], Lyubimova I.L. [5], Myslyakova Yu.G. [6], Naidenko I.S. [7], Perkova V.G. [8], Petrishcheva I.O. [9], Rozhkova A.Yu. [11], Rybina M.N. [1], Tyukavkina N.M. [12], Usova N.V. [6], Yakubovsky I.V. [5] and others.

In his work, Petrishchev I.O. [9] generalized the problems of the educational process digitalization. In particular, the change in teacher's role, teaching staff unpreparedness for the active implementation and use of digital technologies. Students, in turn, do not perceive electronic resources as academic format. As a result, education process participants are not prepared to transfer to the digital space as educational environment.

A team of authors [10] identified the problems and prospects of the digital transformation of education in Russia and China.

It is worth emphasizing that in the context of digital economy and a high level of competition between educational institutions, one of the essential factors is the educational process digitization, as well as convenience for providers and receivers of educational services.

In their works, Naydenko I.S. [7] and Velichko O.A. [7] also addressed the problems and prospects of the digital technologies introduction in higher education. The authors explained, that, although universities take a close look at the development of digital education at the current development stage, there are still lots of problems, including insufficient provision of the required equipment for the teaching staff, lack of methodological tools for the online courses development, low level of digital skills of the teaching staff and lack of feedback from students in the learning process.

In the course of the research, such methods as analysis, comparison, grouping were employed.

\section{Results}

Digitization of various industries and fields of activity has become a national priority over the past few years. And in certain sectors the effect of digital technologies introduction can be seen almost immediately. In turn, the education sector cannot demonstrate efficiency in almost real time, owing to the sector specifics.

Thus, on the one hand, educational services provided in the framework of education sector, being a separate system, are currently in demand with prospective students, which is expressed in high competition for places and training programs representation at universities. For example, the growing demand for educational services in "Law" first led to an increase in supply, as many universities launched training in this field of education, and soon resulted in an excessive surplus of graduates in the market.

On the other hand, it is the education sector that provides the real sector with qualified staff and, at the same time, should foresee the training trends in the medium and long term, in order to ensure the national economy competitiveness, providing highly qualified graduates in the high-demanded training fields.

Moreover, it is important to take into account how exactly educational services are provided and how comfortable and efficient the learning format is for the participants of the education process.

In modern conditions, educational services digitization, as well as the formation and development of a segment of digital educational services, is gaining great relevance.

In the authors' point of view, a digital educational service is a type of economic activity carried out in digital space using the Internet and the necessary software, aimed at meeting the needs for certain skills, knowledge and competencies necessary to carry out certain professional activities. 
There are certain reasons that provided for the educational services transformation and transition to digital space in modern conditions.

First, documents were adopted at the state level aiming at the digital economy development in the Russian Federation.

Second, educational institutions should be constantly transforming and considering their professional activities in the longer term, taking into account the specific demands of the prospective university students and the priorities of the socio-economic development.

Third, the impact of globalization and increasing competition in the global educational services market stimulates the improvement of the activities of the national educational institutions.

The Okinawa Charter for the Global Information Society, adopted in 2000, was the starting point for the educational services digitization. When developing national policy documents, the "Building the information society - a global challenge in the new millennium" Declaration of Principles and the Tunis Commitment Action Plan, adopted in 2003 and 2005 respectively, were also considered.

From now forth, a number of strategic documents were adopted at national level regulating digital economy development and digital technologies introduction in various fields of activity.

So, in 2008, the Strategy for the information society development was approved at national level, aimed at improving the quality of life, ensuring Russia's competitiveness, advancing economic, socio-political, cultural and spiritual fields of social life, improving the public administration system based on the use of information and telecommunication technologies.

In 2017, a new Strategy for the information society development was adopted, focusing on knowledge society development. The main tasks are digital economy formation and human potential development. The strategic document developers highlight that the information space development is impossible without improving the knowledge exchange mechanisms, the use and development of various educational technologies for educational programs implementation, namely distance and e-learning.

The "Digital Economy of the Russian Federation" program was enacted in 2008 and is directed at developing human resources for the digital economy, digital infrastructure and information security and at public administration digitalization.

The important strategic documents for the RF national economy development are 2014 state programs "Information Society" and "Economic development and innovative economy".

The main goal of the first one is to improve the quality of life and work of citizens, to improve business conditions for organizations and to develop the national economic potential based on digital technologies.

The second one is to create favorable business environment, to improve innovative business activity and to increase public administration efficiency.

Although they concentrate on digital technologies development in education, it is education that provides for target indicators achievement.

More specifically, the use of information and communication technologies is impossible without the necessary level of knowledge among the population, as well as without employees with the necessary competencies to implement and use digital technologies in professional activities.

Moreover, ensuring the national economy competitiveness is impossible without digital technologies.

If we turn to industry documents, here are the following important ones.

In October 2016, the priority project "Modern digital educational environment in the Russian Federation" [13] was adopted, which was planned for until 2021. In its framework 
the goal was the digital educational space development, focusing at creating conditions for providing all categories of citizens with an opportunity to receive continuous education. More specifically, the creation by 2018 of conditions for a systematic improvement of the quality and expansion of lifelong education opportunities for all citizens through the development of the Russian digital educational space and increasing the number of students who have mastered online courses up to 11 million people by the end of 2025 .

In addition, the "Education" national project is currently being implemented in the Russian Federation, which provides for several federal projects of the educational system development.

Importantly, the "Education" [14] national project was launched in 01.01.2019for 5 years.

This national project [15] aims at such key areas as updating the content; creation of modern infrastructure; staff training, retraining and advance training; creation of the most efficient mechanisms for the industry management.

In the context of this national project, "Digital Educational Environment" federal project is also operating. Its goals are creating of modern and safe digital educational environment by 2024 to provide accessible education of high quality and of all types and levels.

So, all of these strategic documents clearly focus on the development of the digital infrastructure of the education system and ensuring access to digital educational platforms, regardless of the location of the educational process participants.

Three main stages of digital educational services development can be distinguished.

Table 1. Stages of the digital educational services development (compiled by authors).

\begin{tabular}{|c|c|}
\hline Stage & Essence \\
\hline $\begin{array}{l}\text { Emergence of } \\
\text { digital } \\
\text { educational } \\
\text { services }\end{array}$ & $\begin{array}{l}\text { Computerization stage. At this stage of development, the use of software and } \\
\text { computer equipment itself is observed without the possibility of using digital } \\
\text { space for file exchange. In this period, the computer technology is only } \\
\text { introduced into the activities of educational organizations. }\end{array}$ \\
\hline $\begin{array}{l}\text { Development } \\
\text { of digital } \\
\text { educational } \\
\text { services }\end{array}$ & $\begin{array}{l}\text { Informatization stage. This stage is characterized by the active introduction } \\
\text { of digital technologies into the educational process. However, there is only } \\
\text { access to the Internet, that is provided, and the educational process, that is } \\
\text { computerized. An important point is the need for personal interaction of the } \\
\text { participants of the educational process, that is, there was a clear territorial } \\
\text { aspect. It was in the framework of this stage that the computer transformed } \\
\text { from the category of the object of study into the instrument of knowing and } \\
\text { support to the educational process. }\end{array}$ \\
\hline $\begin{array}{l}\text { Introduction } \\
\text { of digital } \\
\text { educational } \\
\text { services }\end{array}$ & $\begin{array}{l}\text { Digitalization stage. Here the first positions are occupied by the availability } \\
\text { of the Internet for all segments of the population, reducing the digital divide } \\
\text { at the national level, as well as the transformation of the educational process } \\
\text { with the transfer of all stages of education to the Internet. In this case, the } \\
\text { provision of continuous education becomes of critical importance, which } \\
\text { means lifelong learning. In addition, it appears necessary to start building } \\
\text { individual educational trajectories, taking into consideration the } \\
\text { corresponding needs of the individual. }\end{array}$ \\
\hline
\end{tabular}

As can be seen from the table above, the RF higher education system is in the transition to the third stage of digital educational services development.

Under the constant growth of labor intensity and active Internet use, the distance learning format and its digitalization are becoming increasingly important.

In particular, augmented and virtual reality technologies transform material presentation, which increases the efficiency of the learning process.

At the same time, the transition from collective to individual learning trajectory is also rather beneficial. Using mobile technologies any student can now study up at any place and at any convenient time. 
So, today, Internet access, digital inequality reduction and digital competence are of practical importance.

Covid-19 pandemic became a catalyst for introduction and active use of digital technologies in educational process and helped to reveal digitalization gaps in education and in all spheres of social life.

Further, let us consider the statistics illustrating digitization at the national level.

To identify higher education development trends, let us focus on the dynamics of electronic and distance educational programs.

First, consider the dynamics of the number of organizations implementing educational programs of higher education (Table 2).

Table 2. Dynamics of the number of organizations implementing higher learning educational programs [16].

\begin{tabular}{|c|c|c|c|}
\hline & \multicolumn{3}{|c|}{ Educational institutions } \\
\cline { 2 - 4 } & State & Private & Total \\
\hline 2016 & 502 & 316 & 818 \\
\hline 2017 & 500 & 266 & 766 \\
\hline 2018 & 496 & 245 & 741 \\
\hline 2019 & 495 & 229 & 724 \\
\hline 2020 & 497 & 213 & $(-13,2)$ \\
\hline $\begin{array}{c}\text { Growth rate } \\
2020 / 2016(\%)\end{array}$ & $(-1,0)$ & $(-32,6)$ & $(-108,0)$ \\
\hline $\begin{array}{c}\text { D number } \\
2020 / 2016 \text { (units) }\end{array}$ & $(-5,0)$ & $(-103,0)$ & \\
\hline
\end{tabular}

As is seen from the table above, state universities prevail, although total numbers are reducing.

In the time period under research, there is a decrease in the total number of educational organizations, which is, first of all, owing to a decrease in private educational institutions. So, the share of state educational institutions increased from $61.4 \%$ in 2016 to $70 \%$ in 2020 , although in 2016 - 2020 the number of state educational institutions decreased by only 5 educational organizations, as opposed to the private ones, where the reduction was 103 universities (32.6\%). Only in 2020, 16 universities (7\%) withdrew from the national educational services market.

The development trends at bachelor's, specialist's and master's levels are of particular interest for the research.

The total number of educational programs increased $(+15.8 \%)$ over the analyzed period of time. In terms of structure, the growth rate of the number of master's programs in $2016-$ 2020 was $23.4 \%$ (3110 units), the increase in baccalaureate programs was $15.7 \%$ (3699 units), while the number of specialty educational programs decreased by 331 units $(-7.9 \%)$.

Considering baccalaureate programs, it can be noted that distance learning technologies gained momentum. For instance, in 2016 - 2020, the share increased from $11.69 \%$ to $54.01 \%$. In quantitative terms, the increase was 11992 educational programs. The use of e-learning occupies the second place. Although these educational technologies enjoyed greater demand, such programs are fewer in number. The increase was $139.2 \%$ with $65.4 \%$ in 2020 only. The share of network training programs is insignificant. The increase was only 241 units $(49.1 \%)$. Moreover, in the total number of baccalaureate educational programs, the share does not exceed $3 \%$.

Things are different for the specialty programs. The total number decreased by $7.9 \%$ ( 331 programs), although since 2018 there has been a constant increase. In terms of the demand for network learning, electronic and distance technologies, the figures are similar to the baccalaureate level. 
For the master's degree, the demand for the network learning form is also insignificant and amounts to less than $4 \%$. In general, the increase was $16 \%$ (88 educational programs) over 5 years. The share of master's programs using distance learning technologies reached $56.2 \%$ in 2020 , and $43.73 \%$ - with the use of e-learning. In general, over 5 years, distance educational technologies have grown by $876.8 \%$ ( 8286 programs), and the growth rate of electronic technologies is $146.1 \%(4264 \%)$.

Generally, 2020 became a catalyst for the transition to distance educational technologies and e-learning due to both objective reasons connected with global development trends, and theCovid-19 pandemic.

Further, the dynamics of the number of students, both as a whole and by educational levels, will be explored.

During the analyzed period of time, a decrease in the total number of students across the entire set of educational programs $(7.9 \%)$ was revealed. In terms of educational programs specifically, there is a $14.9 \%$ reduction in bachelor's educational programs $(-489769$ students). Meanwhile, the increase was $11.7 \%$ (81,417 students) and 132\% (59,660 students) in the specialist's and master's educational programs respectively.

Over the analyzed period, the share of baccalaureate students decreased from $74.1 \%$ in 2016 to $68.4 \%$ in 2020 , while at the specialist's level the increase was from $15.7 \%$ in 2016 to $19 \%$ in 2020 , and at master's it made $10.2 \%$ and $12.6 \%$ respectively.

For the baccalaureate programs, with the generally decreased number of students, the elearning programs increased by $68.5 \%$ (438,970 students), network training increased by 98.5\% (7776 students) and distance learning technologies - by $277.1 \%$ (968882 students).

As for the specialty programs, the increase in the number of students was $11.7 \%(81,417$ students), and the most high-demanded are educational programs using distance learning technologies. The increase in 5 years was $1159 \%$ (337,058 students). The increase in the number of students using e-learning was $164.7 \%$ (176,892 students).

At master's level, there is an increase in the number of students by $13.2 \%(59660$ students), a sharp increase in the demand for educational programs using distance educational technologies (775.5\% or 223471 students) with e-learning being the second one in demand (74.9\% or $114369 \%)$. Network form of education is also expanding, but not so fast. Here, the increase was only $2.9 \%$ (3136 students) in 5 years.

Next issue to be considered in more detail is the network form.

Over the period under research, there is an increase in the indicators of the "total number of organizations with contracts for the educational programs implementation using the network form" and the "total number of foreign organizations with contracts for the educational programs implementation using the network form". In this case the values of the indicators vary significantly from year to year.

In 2020, the number of organizations with contracts on network interaction decreased in all educational programs.

For foreign organizations master's and bachelor's programs are of greatest interest, while there is limited or no interest in the network form of specialty programs.

\section{Discussion}

For the further advancement of digital educational services, it is important to actively develop local innovative solutions, and also to scale up the successful practice of using digital technologies, which will increase the competitiveness and attractiveness of educational institutions among the target audience.

Moreover, the format and structure of educational course presentation should be revised considering digital opportunities and the need to build individual educational trajectories, 
which becomes even more relevant in turbulent external environment and changes in the educational services perception.

Quite often, educational services are wrongly considered as interaction between teacher and student in terms of classroom load. In fact, it also includes digital libraries, digital dean's offices, departments and other structural units to providing integrated digital approach to digital educational services.

When developing and implementing digital educational services, it is necessary to consider specifics of each market segment that the educational organization focuses on, which will directly influence the course structure, the choice of digital teaching methods and digital platforms. Different target segments have different motivation and digital competence, which may lead to certain risks affecting the quality of digital educational services provided.

\section{References}

1. E.N. Bykovskaya, M.N. Rybina, Society: soc., psych., pedag. 6(74) (2020)

2. O.I. Veselitsky, New information technologies in education: using "1C" technologies to develop the digital economy competencies. Coll. of res. pap., the 18th inter.sc. (2018)

3. V.Yu. Dogadina, Prob.of Econ.4(42) (2019)

4. N.V. Latova, Yu.V. Latov, J. of Inst. Res. 12(2) (2020)

5. I.L. Lyubimov, I.V. Yakubovsky, J. N. Econ. As. 2(46) (2020)

6. Yu.G. Myslyakova, N.V. Usova, Pub. Adm. El. bul. 82 (2020)

7. I.S. Naidenko, O.A. Velichko, Hum. Sc.Bul. 5(2020)

8. V.G. Perkova, Vest. NSUEM 1 (2011)

9. I.O. Petrishchev, Uch. Zap. El. Sc.J. of KSU 2(54) (2020)

10. A.Yu. Uvarov, S. Wang, Ts. Kahn et al., Digital transformation of education and artificial intelligence, Chin. Conf. of ed. Res. (HSE, 2019)

11. A.Yu. Rozhkova, M.V. Vasiljeva, Sc. Bul. of S. Inst. of Man, 1(29) (2020)

12. N.M. Tyukavkin, Exp.: th. and pract. 1(1) Passport of the priority project "Modern digital educational environment in the Russian Federation" (ConsultantPlus, 2016)

13. Passport of the national "Education", https://minobrnauki.gov.ru/files/NP_Obrazovanie.htm

14. Passport of the national "Education", https://minobrnauki.gov.ru/files/NP_Obrazovanie.htm

15. Form N VPO-1 "Information about the organization carrying out educational activities in educational programs of higher education - baccalaureate programs, specialist programs, master's programs", https://minobrnauki.gov.ru/action/stat/highed/ 